\title{
ANALISIS WACANA KRITIS PADA NOVEL "PEREMPUAN DI TITIK NOL" KARYA NAWAL EL SAADAWI DITINJAU DARI TOKOH DAN PERWATAKAN, KONFLIK SERTA AMANAT
}

\author{
Sun Suntini \\ Program Studi Pendidikan Bahasa dan Sastra Indonesia \\ Fakultas Keguruan dan Ilmu Pendidikan Universitas Kuningan
}

\begin{abstract}
ABSTRAK
Wacana merupakan satuan kebahasaan yang paling lengkap dan paling kompleks dibandingkan dengan satuan kebahasaan yang lain. Kompleks di sini artinya dalam wacana banyak sekali unsur pendukungnya, satuan pendukung kebahasaan yang lain diantaranya fonem, morfem, frasa, klausa, dan kalimat. Suatu tulisan dapat dikatakan wacana jika memenuhi syarat dalam pembentukan suatu wacana diantaranya adanya kohesi dan koherensi. Kohesi adalah kepaduan bentuk secara srtuktural contoh adanya referensi, substitusi, ellipsis, konjungsi dan sebagainya, sedangkan koherensi berhubungan dengan makna. Berdasarkan media penyampaiannya wacana dapat dibagi dua yaitu ada wacana lisan dan ada wacana tulis. Wacana lisan yaitu jenis wacana yang disampaikan secara lisan atau langsung, sedangkan wacana tulis yaitu wacana yang disampaikan melalui tulisan. Pada dasarnya wacana itu lisan karena pertama kali manusia berkomunikasi secara lisan, tetapi seiring perkembangan zaman saat ini lebih banyak wacana tulis dibandingkan wacana lisan. Analisis wacana kritis (AWK) adalah sebuah upaya atau proses untuk memberi penjelasan (realitas sosial) yang mau atau sedang dikaji oleh seseorang atau kelompok yang mempunyai tujuan tertentu untuk memperoleh yang diinginkan (Yoce Aliah Darma, 2009: 49). Analisis yang dimaksud adalah upaya pengungkapan maksud tersembunyi dari penulis yang mengemukakan suatu pernyataan. Permasalahan dalam penelitian ini yaitu 1) Bagaimanakah perwatakan tokoh pada novel "perempuan di titik nol" karya Nawal el Saadawi ?2) Bagaimanakah konflik pada novel "perempuan di titik nol" karya Nawal el Saadawi ?3) Bagaimanakah amanat pada novel "perempuan di titik nol" karya Nawal el Saadawi?4) Bagaimanakah analisis wacana kritis pada perwatakan dalam novel "perempuan di titik nol" karya Nawal el Saadawi ?5) Bagaimanakah analisis wacana kritis pada konflik dalam novel "perempuan di titik nol" karya Nawal el Saadawi?6) Bagaimanakah analisis wacana kritis pada amanat dalam novel "perempuan di titik nol" karya Nawal el Saadawi?Metode yang digunakan adalah deskriptif analitis. Objek penelitian ini adalah novel berjudul "Perempuan Di Titik Nol Karya Nawal el-Saadawi"Setelah dilakukan penelitian terhadapa novel dengan cara dianalisis, hasil kesimpulannya yaitu 1) Tokoh laki-laki dalam novel ini mempunyai karakter cendering berkuasa dalam segala aspek kehidupan terutama menguasai perempuan banyak ketidakadilan yang dialami oleh perempuan.Tokoh perempuannya cenderung lemah sehingga mereka dengan mudah dikuasai dan ditindas oleh kaum laki-laki dan akhirnya mereka tidak percaya lagi dengan laki-laki dan ingin hidup bebas, mereka merasa ikatan rumahtangga merupakan perbudakan bagi kaum perempuan. konflik dalam novel ini terjadi anatar laki-laki dan
\end{abstract}


perempuan dikarenakan kekuasaan laki-laki terhadap perempuan dan pada akhirnya perempuan kehilangan kepercayaan terhadap laki-laki. Amanat dari novel ini adalah tentang kekuasaan/hegemoni laki-laki terhadap perempuan dan akhirnya perempuan memilih jadi feminis.

Kata Kunci : Wacana Kritis, Tokoh dan Perwatakan, Amanat

\section{PENDAHULUAN}

Analisis wacana kritis (AWK) adalah salah satu upaya untuk mengungkapkan maksud tersembunyi dari pernyataan penulis. AWK bukan hanya analisis studi bahasa tetapi analisis secara mendalam tentang maksud dari tulisan atau pernyataan penulis, bahasa dalam analisis wacana kritis selain pada teks juga konteks bahasa sebagai alat yang dipakai untuk tujuan tertentu termasuk praktik idiologi.

Menurut Teun van Dijk (dalam Yoce, 2009:51) AWK digunakan untuk menganalis wacana-wacana kritis seperti wacana politik, ras, genre, kelas sosial, hegemoni dan lainlain. Ada pun prinsip-prinsip ajaran AWK 1. Membahas masalah-masalah sosial 2. Mengungkap bahwa relasi kekuasaan adalah diskursif 3. Mengungkap budaya 4. Bersifat ideologi 5. Bersifat historis 6. Mengemukakan hubungan antara teks dan masyarakat 7. Bersifat interpretatif dan eksplanatori.

Selain prinsip dalam analisis wacana kritis ada pula karakteristik yang dimiliki oleh AWK. Berikut menurut Teun A. van Dijk, Fairclough dan Wodak (Eriyanto, 2005:813) 1.tidakan yaitu wacana diasosiasikan sebagai bentuk interaksi 2 . Konteks yaitu latar, situasi, peristiwa, dan kondisi 3. Historis yaitu menempatkan wacana dalam konteks sosial tertentu 4. Kekuasaan yaitu mempertimbangkan elemen kekuasaan dalam analisisnya5. Ideologi dimaksudkan untuk mengatur masalah tindakan dan praktik individu atau anggota suatu kelompok.

Dalam kehidupan sehari-hari AWK dapat digunakan untuk membangun kekuasaan, ilmu pengetahuan baru, regulasi dan normalisasi, serta hegemoni, selain itu AWK juga dapat digunakan untuk mengkritik kehidupan sosial yang tercermin dalam teks. Wacana yang banyak mengkritik misalnya pada karya sastra puisi, cerpen, novel, atau teks drama. AWK bertujuan untuk memahami masalah sosial dalam hubungannya antara ideologi dengan kekuasaan.

\section{TINJAUAN PUSTAKA}

\section{A. Ikhwal Wacana}

Pengertian wacana menurut para ahli agak berbeda, misalnya menurut Yoce Aliah Darma ( 2009: 3) wacana merupakan rangkaian ujar atau rangkaian tidak tutur yang mengungkapkan suatu hal yang disajikan secara teratur, sistematis, dalam satu kesatuan koheren, yang dibentuk oleh unsur-unsur segmental dalam sebuah wacana yang paling besar. Sedangkan menurut Tarigan(1987: 25) wacana adalah satuan kebahasaan terlengkap di atas kalimat atau klausa yang teratur adanya kohesi dan koherensi baik lisan maupun tulisan serta mempunyai awal dan akhir yang nyata. 
Menurut Syamsuddin (1992: 5) wacana merupakan rangkaian ujar atau rangkaian tindak tutur yang mengungkapkan suatu hal yang disajikan secara teratur, sistematis dalam satuan yang koheren dibentuk oleh unsure segmental dan non segmental.

\section{B. Analisis Wacana Kritis}

Menurut Teun van Dijk (dalam Yoce, 2009:51) AWK digunakan untuk menganalis wacana-wacana kritis seperti wacana politik, ras, genre, kelas sosial, hegemoni dan lain-lain. Ada pun prinsip-prinsip ajaran AWK 1. Membahas masalah-masalah sosial 2. Mengungkap bahwa relasi kekuasaan adalah diskursif 3. Mengungkap budaya 4 . Bersifat ideologi 5. Bersifat historis 6. Mengemukakan hubungan antara teks dan masyarakat 7. Bersifat interpretatif dan eksplanatori.

Selain prinsip dalam analisis wacana kritis ada pula karakteristik yang dimiliki oleh AWK. Berikut menurut Teun A. van Dijk, Fairclough dan Wodak (Eriyanto, 2005:813) 1.tidakan yaitu wacana diasosiasikan sebagai bentuk interaksi 2. Konteks yaitu latar, situasi, peristiwa, dan kondisi 3. Historis yaitu menempatkan wacana dalam konteks sosial tertentu 4. Kekuasaan yaitu mempertimbangkan elemen kekuasaan dalam analisisnya5. Ideologi dimaksudkan untuk mengatur masalah tindakan dan praktik individu atau anggota suatu kelompok.

Dalam kehidupan sehari-hari AWK dapat digunakan untuk membangun kekuasaan, ilmu pengetahuan baru, regulasi dan normalisasi, serta hegemoni, selain itu AWK juga dapat digunakan untuk mengkritik kehidupan sosial yang tercermin dalam teks. Wacana yang banyak mengkritik misalnya pada karya sastra puisi, cerpen, novel, atau teks drama. AWK bertujuan untuk memahami masalah sosial dalam hubungannya antara ideologi dengan kekuasaan.

\section{Karakteristik Analisis Wacana Kritis}

\section{a. Tindakan}

Dalam analisis wacana kritis wacana tidak semata-mata dipahami sebagai studi bahasa. Menurut Aliah Darma (2014 :135) bahasa dianalisis bukan saja dengan menggambarkan dari segi aspek kebahasaan tetapi mengungkapkannya dengan tindakan. Analisis wacana menyelidiki kelompok sosial yang bertarung melalui bahasa. Wacana kritis juga merupakan wacana yang tidak netral berbagai pendekatan digunakan untuk beradu pendapat antara kelompok yang satu dengan kelompok yang lain. Ada yang mengatasnamakan emansipasi sehingga dianggap memihak kelompok-kelompok sosial yang tertindas.

Berdasarkan uraian di atas dapat disimpulkan bahwa wacana kritis tidak hanya sebuah tulisan tetapi merupakan tidakan dari penulis , wacana ini mengandung tujuan misalnya untuk mendebat, membujuk ,bereaksi dan sebagainya. Wacana ini juga merupakan sesuatu yang diekpresikan secara sadar dan terkontrol.

Beberapa wacana kritis yang ada di Indonesia misalnya pada novel banyak mengandung tujuan-tujuan tertentu untuk mempengaruhi atau mendebat suatu golongan atau kelompok. Untuk memahami wacana ini dibutuhkan pengetahuan 
yang memadai karena bahasanya banyak yang tersirat, oleh karena itu bnayak bermunculan penelitian-penelitian mengenai analisis wacana kritis.

\section{b. Konteks}

Secara umum konteks dapat diartikan sesuai dengan situasi dan kondisi atau sesuai tempat. Dalam hal ini yang termasuk konteks wacana kritis yaitu latar, situasi, peristiwa, dan kondisi. Menurut Aliah Darma (2014:137) konteks pemakaian bahasa dapat dibagi menjadi empat macam yaitu : 1. Konteks fisik meliputi tempat terjadinya pemakaian bahasa dalam suatu komunikasi, objek yang disajikan dalam peristiwa komunikasi itu merupakan tindakan atau prilaku dari para peran dalam peristiwa tersebut. 2. Konteks epistemis atau latar belakang pegetahuan yang sama-sama diketahui oleh pembicara maupun pendengar, 3. Konteks linguistik terdiri atas kalimat-kalimat ,4. Konteks sosial yaitu relasi sosial dan latar setting yang melengkapi hubungan antara pembicara dan pendengar.

\section{c. Historis}

Wacana dilihat dari historis menempatkan wacana dalam konteks sosial artinya pemahaman wacana ini hanya dapat diperoleh apabila kita bisa memberikan konteks historis tertentu, misalnya situasi sosial politik pada saat itu dapat dianalisis dengan wacana kritis.

\section{d. Kekuasaan}

Dalam analisis wacana kritis juga mempertimbangkan kekuasaan, konsep kekuasaan adalah salah satu kunci hubungan antara wacana dengan masyarakat, seperti kekuasaan laki-laki atas perempuan, kekuasaan kulit putih terhadap kulit hitam, kekuasaan perusahaan dalam bentuk dominasi terhadap bawahan. Kekuasaan ini dibutuhkan untuk melihat apa yang disebut sebagai kontrol. Satu orang atau kelompok mengontrol kelompok lain, dan kelompok dominan lebih mempunyai akses daripada kelompok yang tidak dominan. Power atau kekuasaan atau social power merupakan kajian sentral dari critical discourse. Power digunakan untuk mengontrol tindakan dan pikiran suatu kelompok dalam bentuk uang, status, popularitas, pengetahuan, informasi, budaya dan komunikasi. Power dibedakan berdasarkan pada sumber daya yang menggunakannya misalnya orang kaya punya power uang yang banyak, seorang profesor punya power karena pengetahuannya.

Kekuasaan suatu kelompok terintegrasi dalam bentuk hokum, peraturan, norma, kebiasaan atau consensus yang biasa disebut hegemoni. Adapun sumber kekuasaan berupa politik, media, atau ilmu. Berikutnya proses mempengaruhi pikiran seseorang dan secara tidak langsung mengontrol tindakkannya, ketika pikiran seseorang telah terpengaruh oleh teks dan pembicaraan ini membuktikan bahwa wacana dapat mengontrol tindakan orang melalui persuasi dan manipulasi. 


\section{e. Ideologi}

Selain kekuasaan dalam analisis wacana kritis yaitu di bidang ideologi. Ideologi dibangun oleh kelompok yang dominan dengan tujuan untuk mereproduksi dan melegitimasi dominasi mereka (Aliah Darma, 2014:142).

Implikasi penting dalam ideologi yaitui ideology yaitu pertama ideologi secara inheren bersifat sosial, kedua ideologi digunakan secara internal diantara anggota kelompok atau komunitas. Ideologi dapat membedakan anatara satu kelompok dengan kelompok lain. Dalam teks akan muncul cerminan dari ideology seseorang apakah feminis, antifeminis, kapitalis, rasis, dan sosialis. Ideologi dalam hal ini adalah seperangkat kategori yang dibuat dalam keadaan sadar oleh sekelompok yang berkuasa atau dominan dimana mereka menggunakannya untuk mendominasi kelompok lain yang tidak dominan.

\section{Ikhwal Sastra}

Sastra merupakan karya seni yang menggunakan media sebagai alat ungkapnya baik lisan maupun tulisan, dalam dunia sastra sedikitnya ada dua hal yang menjadi titik perhatian yaitu yang pertama isi dan kedua struktur dalam penyajiannya. Dilihat dari isi sastra mempunyai banyak segi misalnya : cinta, sosial, peradaban, cita-cita, serta moral.

Sastra sebagai karya seni tidak terlepas dari nilai estetik tetapi selain itu ada hal yang tidak kalah penting selain nilai keindahan yaitu adanya nilai-nilai yang membawa manusia pada jalan kebenaran. Seperti yang diungkapkan Atar Semi bahwa sastra adalah karya seni, karena itu ia mempunyai sifat yang sama dengan karya seni yang lain, seperti seni suara, seni lukis, seni pahat, dan lain-lain. Tujuannya pun sama yaitu untuk membantu manusia menyingkapkan rahasia keadaannya, untuk memberi makna pada eksistensinya, serta untuk membuka jalan ke kebenaran. Yang membedakannya dengan seni yang lain, adalah bahwa sastra memiliki aspek bahasa. (Semi, 1989 : 39)

Karya sastra merupakan salah satu media yang bisa mengangkat harkat manusia melalui isinya yang mengandung nilai-nila oleh karena itu sebuah karya baru bisa dikatakan bernilai sastra jika di dalamnya mengandung nilai-nilai yang bermanfaat untuk kepentingan hidup manusia. Seperti yang dikatakan Aan

Sugianto Mas bahwa sebuah karya seni dapat dikatakan sebagai karya yang bernilai sastra bukan hanya karena bahasanya yang indah, beralun-alun, penuh dengan irama dan perumpamaan, melainkan harus dilihat secara keseluruhan, dari nilai-nilai estetika, nilai-nilai moral, dan nilai-nilai konsepsi yang terdapat dalam karya sastra tersebut (Sugianto Mas, 2002 : 9).

Dari pendapat di atas dapat disimpulkan bahwa sastra adalah karya seni hasil cipta manusia yang menggunakan bahasa sebagai medianya, yang bertujuan memberi makna pada eksistensi manusia dan untuk membuka jalan kebenaran. 


\section{METODOLOGI PENELITIAN}

Metode penelitian yang digunakan adalah metode deskriptif analitis. Metode ini bertujuan untuk menggambarkan mengenai situasi atau kejadian-kejadian suatu subjek yang mengandng fenomena dengan cara mengumpulkan data, menyusun, menjelaskan, kemudian menganalisis data yang ada berdasarkan standar ukuran kualitas. Dalam penelitian ini difokuskan untuk menganalisis wacana kritis pada novel "Perempuan Di Titik Nol Karya Nawal el-Saadawi” ditinjau dari tokoh dan perwatakan, konflik serta amanat.

\subsection{Objek Penelitian}

Objek penelitian ini adalah novel berjudul "Perempuan Di Titik Nol Karya Nawal el-Saadawi".

\subsection{Instrumen Penelitian}

Dalam penelitian kualitatif yang menjadi intrumen adalah peneliti itu sendiri, kemampuan peneliti dalam bidang ilmu yang sedang diteliti, tetapi untuk mempermudah penelitian ini maka penulis membuat pedoman analisis yang digunakan untuk menganalisis novel "Perempuan Di Titik Nol" karya Nawal el-Saadawi., yaitu sebagai berikut:

Pedoman Analisis Tokoh dan Perwatakan

\begin{tabular}{|l|l|l|l|}
\hline No. & Naman Tokoh & Perwatakan & Analisis \\
\hline 1 & & & \\
\hline 2 & & & \\
\hline 3 & & & \\
\hline 4 & & & \\
\hline 5 & & & \\
\hline
\end{tabular}

Pedoman Analisis Konflik

\begin{tabular}{|l|c|c|}
\hline No. & Konflik & Analisis \\
\hline 1 & & \\
\hline 2 & & \\
\hline 3 & & \\
\hline 4 & & \\
\hline 5 & & \\
\hline
\end{tabular}

Pedoman Analisis Amanat

\begin{tabular}{|c|c|c|}
\hline No. & Amanat & Analisis \\
\hline 1 & & \\
\hline 2 & & \\
\hline
\end{tabular}




\begin{tabular}{|l|l|l|}
\hline 3 & & \\
\hline 4 & & \\
\hline 5 & & \\
\hline
\end{tabular}

Pedoman Analisis Wacana Kritis berdasarkan tokoh dan perwatakan

\begin{tabular}{|l|l|l|l|l|l|l|}
\hline No. & $\begin{array}{l}\text { Tokoh Dan } \\
\text { Perwatakan }\end{array}$ & Tindakan & Konteks & histori & kekuasaan & ideologi \\
\hline 1 & & & & & & \\
\hline 2 & & & & & & \\
\hline 3 & & & & & & \\
\hline
\end{tabular}

Pedoman Analisis Wacana Kritis berdasarkan konflik

\begin{tabular}{|c|c|c|c|c|c|c|}
\hline No & konflik & Tindakan & Konteks & histori & kekuasaan & ideologi \\
\hline 1 & $\begin{array}{l}\text { Firdaus } \\
\text { perwatak } \\
\text { an lemah }\end{array}$ & $\begin{array}{l}\text { Pikiran, } \\
\text { perkataan } \\
\text { dan } \\
\text { tindakannya } \\
\text { selalu kalah } \\
\text { dengan } \\
\text { orang lain } \\
\text { sehingga } \\
\text { tidak sesuai } \\
\text { dengan } \\
\text { harapan }\end{array}$ & $\begin{array}{l}\text { Setiap } \\
\text { peristiwa } \\
\text { yang } \\
\text { terjadi } \\
\text { Firdaus } \\
\text { sebagai } \\
\text { korban }\end{array}$ & $\begin{array}{l}\text { Keputusan } \\
\text { Firdaus } \\
\text { dipengaruhi } \\
\text { oleh } \\
\text { pengalaman- } \\
\text { pengalaman } \\
\text { hidupnya }\end{array}$ & $\begin{array}{l}\text { Firdaus } \\
\text { selalu } \\
\text { tertekan } \\
\text { dengan } \\
\text { semua } \\
\text { orang } \\
\text { yang dekat } \\
\text { dengannya } \\
\text { terutama } \\
\text { laki-laki }\end{array}$ & $\begin{array}{l}\text { Termasuk } \\
\text { feminisme }\end{array}$ \\
\hline 2 & $\begin{array}{l}\text { Ibu } \\
\text { Firdaus }\end{array}$ & $\begin{array}{l}\text { Apa yang } \\
\text { dilakukan } \\
\text { oleh ibunya } \\
\text { Firdaus } \\
\text { sebagai } \\
\text { seorang ibu } \\
\text { rumah } \\
\text { tangga } \\
\text { memang } \\
\text { wajar } \\
\text { mengurus } \\
\text { suami dan } \\
\text { anak tetapi } \\
\text { jika sudah } \\
\text { terjadi }\end{array}$ & $\begin{array}{l}\text { Ibu } \\
\text { Firdaus } \\
\text { sebagi } \\
\text { korban } \\
\text { dari } \\
\text { kekersan } \\
\text { dalam } \\
\text { rumahtang } \\
\text { ga yang } \\
\text { dilakukan } \\
\text { oleh } \\
\text { suaminya }\end{array}$ & $\begin{array}{l}\text { Sudah jadi } \\
\text { kebiasaan } \\
\text { seorang isteri } \\
\text { mengurus } \\
\text { anak dan } \\
\text { suami dan } \\
\text { menuruti } \\
\text { semua } \\
\text { keinginan } \\
\text { suami }\end{array}$ & $\begin{array}{l}\text { Ibu } \\
\text { Firdaus } \\
\text { dibawah } \\
\text { kekuasaan } \\
\text { ayahnya }\end{array}$ & Feminisme \\
\hline
\end{tabular}




\begin{tabular}{|c|c|c|c|c|c|c|}
\hline & & $\begin{array}{l}\text { kekerasan } \\
\text { maka itu } \\
\text { sudah } \\
\text { melewati } \\
\text { batas ini } \\
\text { terjadi pada } \\
\text { ibunya } \\
\text { Firdus }\end{array}$ & & & & \\
\hline 3 & $\begin{array}{l}\text { Ayah } \\
\text { Firdaus }\end{array}$ & $\begin{array}{l}\text { Sebagai } \\
\text { laki- } \\
\text { laki/suami } \\
\text { tindakan } \\
\text { ayah Fidaus } \\
\text { tidak sesuai } \\
\text { dengan } \\
\text { makna } \\
\text { seorang } \\
\text { suami yang } \\
\text { seharusnya } \\
\text { melindungi } \\
\text { tetapi malah } \\
\text { menyiksa } \\
\text { isteri dan } \\
\text { anknya }\end{array}$ & $\begin{array}{l}\text { Peristiwa } \\
\text { ini terjadi } \\
\text { dalam } \\
\text { kehidupan } \\
\text { rumah } \\
\text { tangga }\end{array}$ & $\begin{array}{l}\text { Jika dilihat } \\
\text { dari sejarah } \\
\text { kejadian } \\
\text { dalam } \\
\text { rumahtangga } \\
\text { seperti ini } \\
\text { sudah terjadi } \\
\text { sejak lama }\end{array}$ & $\begin{array}{l}\text { Ia } \\
\text { berkuasa } \\
\text { terhadap } \\
\text { isteri dan } \\
\text { anaknya }\end{array}$ & Hegemoni \\
\hline 4 & $\begin{array}{l}\text { Paman } \\
\text { Firdaus }\end{array}$ & $\begin{array}{l}\text { Tindakanny } \\
\text { a sebagai } \\
\text { seorang } \\
\text { paman ia } \\
\text { cukup baik } \\
\text { tetapi ia } \\
\text { juga ikut } \\
\text { serta } \\
\text { melecehaka } \\
\text { n } \\
\text { perempuan }\end{array}$ & $\begin{array}{l}\text { Situasi } \\
\text { lemah } \\
\text { terhadap } \\
\text { isterinya }\end{array}$ & $\begin{array}{l}\text { Isterinya } \\
\text { orang berada } \\
\text { dan } \\
\text { berpendidika } \\
\text { n tinggi } \\
\text { sehingga } \\
\text { isterinya } \\
\text { lebih ditakuti } \\
\text { daripada } \\
\text { dicintai }\end{array}$ & $\begin{array}{l}\text { Di bawah } \\
\text { kekuasaan } \\
\text { isterinya }\end{array}$ & Feminisme \\
\hline 5 & $\begin{array}{l}\text { Istri } \\
\text { paman } \\
\text { Firdaus }\end{array}$ & $\begin{array}{l}\text { Menguasai } \\
\text { suami }\end{array}$ & $\begin{array}{l}\text { Situasi ia } \\
\text { lebih dari } \\
\text { suaminya }\end{array}$ & $\begin{array}{l}\text { Ia seorang } \\
\text { perempuan } \\
\text { terpelajar }\end{array}$ & $\begin{array}{l}\text { Ia } \\
\text { berkuasa } \\
\text { atas } \\
\text { suaminya }\end{array}$ & Feminisme \\
\hline 6 & Suami & Kejam dan & Lebih & Karena & Ia sangat & Hegemoni \\
\hline
\end{tabular}




\begin{tabular}{|c|c|c|c|c|c|c|}
\hline & Firdaus & $\begin{array}{l}\text { semena- } \\
\text { mena } \\
\text { terhadap } \\
\text { isterinya }\end{array}$ & $\begin{array}{l}\text { tinggi dari } \\
\text { isterinya }\end{array}$ & $\begin{array}{l}\text { mempunyai } \\
\text { kekayaan dan } \\
\text { lebih } \\
\text { berpengalam } \\
\text { an }\end{array}$ & $\begin{array}{l}\text { menguasai } \\
\text { isterinya } \\
\text { bahkan } \\
\text { memperbu } \\
\text { dak } \\
\text { isterinya }\end{array}$ & \\
\hline 7 & Bayoumi & $\begin{array}{l}\text { kejam } \\
\text { terhadap } \\
\text { perempuan } \\
\text { lemah }\end{array}$ & $\begin{array}{l}\text { Ia merasa } \\
\text { telah } \\
\text { menolong } \\
\text { jadi harus } \\
\text { ada } \\
\text { imbalanny } \\
\text { a }\end{array}$ & $\begin{array}{l}\text { Ia seorang } \\
\text { laki-laki yang } \\
\text { tidak baik }\end{array}$ & $\begin{array}{l}\text { Ia sangat } \\
\text { berkuasa } \\
\text { terhadap } \\
\text { Firdaus }\end{array}$ & Hegemoni \\
\hline 8 & $\begin{array}{l}\text { Atasan } \\
\text { firdaus }\end{array}$ & $\begin{array}{l}\text { Tidak adil } \\
\text { terhadap } \\
\text { karyawati }\end{array}$ & $\begin{array}{l}\text { Banyak } \\
\text { karyawati } \\
\text { yang mau } \\
\text { dijadikan } \\
\text { pemuas } \\
\text { nafsunya }\end{array}$ & $\begin{array}{l}\text { Pemegang } \\
\text { kekuasaan di } \\
\text { perusahaan }\end{array}$ & $\begin{array}{l}\text { Menguasai } \\
\text { semua } \\
\text { karyawan } \\
\text { dan } \\
\text { karyawati }\end{array}$ & Hegemoni \\
\hline 9 & Ibrahim & $\begin{array}{l}\text { Diawal baik } \\
\text { ternyata } \\
\text { licik }\end{array}$ & $\begin{array}{l}\text { Ingin } \\
\text { memperba } \\
\text { iki } \\
\text { keadaan }\end{array}$ & $\begin{array}{l}\text { Kesewenang- } \\
\text { wenangan } \\
\text { para pejabat } \\
\text { terhadap } \\
\text { karyawannya }\end{array}$ & $\begin{array}{l}\text { Berkuasa } \\
\text { terhadap } \\
\text { fidaus }\end{array}$ & \\
\hline 10 & Marzouk & $\begin{array}{l}\text { Licik dan } \\
\text { ingin } \\
\text { menikmati } \\
\text { hasil kerja } \\
\text { keras orang } \\
\text { lain }\end{array}$ & $\begin{array}{l}\text { Ia seorang } \\
\text { laki-laki } \\
\text { yang } \\
\text { mempuny } \\
\text { ai } \\
\text { kekuatan }\end{array}$ & $\begin{array}{l}\text { Seorang } \\
\text { germo yang } \\
\text { sudah biasa } \\
\text { memeras para } \\
\text { pelacur } \\
\text { dengan dalih } \\
\text { melindungi }\end{array}$ & $\begin{array}{l}\text { Berkuasa } \\
\text { terhadap } \\
\text { Firdaus }\end{array}$ & Hegemoni \\
\hline
\end{tabular}

Pedoman Analisis Wacana Kritis berdasarkan amanat

\begin{tabular}{|l|l|l|l|l|l|l|}
\hline NO & Amanat & Tindakan & Konteks & histori & Kekuasaan & ideologi \\
\hline 1 & & & & & & \\
\hline 2 & & & & & & \\
\hline 3 & & & & & & \\
\hline
\end{tabular}


HASIL PENELITIAN

1. Analisis wacana kritis berdasarkan tokoh dan perwatakan

\begin{tabular}{|l|l|l|l|l|l|l|}
\hline NO & Amanat & Tindakan & Konteks & histori & Kekuasaan & ideologi \\
\hline & & & & & & \\
\hline & & & & & & \\
\hline & & & & & & \\
\hline & & & & & & \\
\hline & & & & & & \\
\hline & & & & & & \\
\hline
\end{tabular}

2. Analisis wacana kritis berdasarkan konflik

\begin{tabular}{|c|c|c|c|c|c|c|}
\hline No & Konflik & Tindakan & Konteks & Histori & kekuasaan & Ideology \\
\hline 1 & $\begin{array}{l}\text { Konflik } \\
\text { antara } \\
\text { Firdaus } \\
\text { dengan } \\
\text { ayahny } \\
\text { a }\end{array}$ & $\begin{array}{l}\text { Tindakan } \\
\text { ayaknya } \\
\text { terhadap } \\
\text { ibunya } \\
\text { membuat } \\
\text { Firdaus } \\
\text { membenci } \\
\text { ayahnya }\end{array}$ & $\begin{array}{l}\text { Situasi } \\
\text { Firdaus } \\
\text { masih kecil } \\
\text { dan tak } \\
\text { punya } \\
\text { kekuatan } \\
\text { untuk } \\
\text { melawan }\end{array}$ & $\begin{array}{l}\text { Seorang } \\
\text { kepala } \\
\text { keluarga } \\
\text { akan } \\
\text { berkuasa di } \\
\text { rumahnya }\end{array}$ & $\begin{array}{l}\text { Ayahnya } \\
\text { jelas orang } \\
\text { yang paling } \\
\text { berkuasa } \\
\text { dirumahnya }\end{array}$ & \\
\hline 2 & $\begin{array}{l}\text { Konflik } \\
\text { Firdaus } \\
\text { dengan } \\
\text { pamann } \\
\text { ya }\end{array}$ & $\begin{array}{l}\text { Tidakan } \\
\text { pamanya } \\
\text { yang } \\
\text { mengawinkan } \\
\text { Firdaus } \\
\text { dengan Syech } \\
\text { Mahmoud } \\
\text { merupakan } \\
\text { kesalahan } \\
\text { besar yang } \\
\text { mengakibatka } \\
\text { n Firdaus } \\
\text { menderia }\end{array}$ & $\begin{array}{l}\text { Firdaus } \\
\text { lemah } \\
\text { karena } \\
\text { menumpang }\end{array}$ & $\begin{array}{l}\text { Ia diurus } \\
\text { oleh } \\
\text { pamannya } \\
\text { sejak kecil }\end{array}$ & $\begin{array}{l}\text { Ia dibawah } \\
\text { kekuasaan } \\
\text { paman dan } \\
\text { isterinya }\end{array}$ & Hegemoni \\
\hline 3 & $\begin{array}{l}\text { Konflik } \\
\text { Firdaus } \\
\text { dengan } \\
\text { suamin } \\
\text { ya }\end{array}$ & $\begin{array}{l}\text { Suami } \\
\text { Firdaus yang } \\
\text { kejam suka } \\
\text { memukul } \\
\text { membuat }\end{array}$ & $\begin{array}{l}\text { Firdaus } \\
\text { lemah }\end{array}$ & $\begin{array}{l}\text { Ia seorang } \\
\text { isteri yang } \\
\text { harus patuh } \\
\text { pada } \\
\text { suaminya }\end{array}$ & $\begin{array}{l}\text { Suaminya } \\
\text { sangat } \\
\text { menguasain } \\
\text { ya }\end{array}$ & Hegemoni \\
\hline
\end{tabular}




\begin{tabular}{|c|c|c|c|c|c|c|}
\hline & & $\begin{array}{l}\text { firdaus pergi } \\
\text { dari rumah }\end{array}$ & & & & \\
\hline 4 & $\begin{array}{l}\text { Konflik } \\
\text { Firdaus } \\
\text { dengan } \\
\text { Bayou } \\
\text { mi }\end{array}$ & $\begin{array}{l}\text { Tindakan } \\
\text { Bayoumi } \\
\text { yang diluar } \\
\text { batas } \\
\text { memperkosa } \\
\text { Firdaus } \\
\text { berkali-kali } \\
\text { dan } \\
\text { menjualnya }\end{array}$ & $\begin{array}{l}\text { Firdaus } \\
\text { tidak punya } \\
\text { pilihan } \\
\text { karena ia } \\
\text { pergi dari } \\
\text { rumah } \\
\text { suaminya }\end{array}$ & $\begin{array}{l}\text { Awalnya ia } \\
\text { ditolong } \\
\text { oleh } \\
\text { bayoumi }\end{array}$ & $\begin{array}{l}\text { Bayoumi } \\
\text { menguasi } \\
\text { Firdaus }\end{array}$ & \\
\hline 5 & $\begin{array}{l}\text { Konflik } \\
\text { antara } \\
\text { Firdaus } \\
\text { dengan } \\
\text { atasann } \\
\text { ya }\end{array}$ & $\begin{array}{l}\text { Tindakan } \\
\text { atasan } \\
\text { terhadap } \\
\text { karyawan } \\
\text { bawahan } \\
\text { yang semena- } \\
\text { mena }\end{array}$ & $\begin{array}{l}\text { Situasinya } \\
\text { dibawah } \\
\text { kekuasaan } \\
\text { atasan }\end{array}$ & $\begin{array}{l}\text { Atasan } \\
\text { selalu lebih } \\
\text { berkuasa }\end{array}$ & $\begin{array}{l}\text { Atasan } \\
\text { menguasai } \\
\text { bawahan }\end{array}$ & hegemoni \\
\hline 6 & $\begin{array}{l}\text { Konflik } \\
\text { Firdaus } \\
\text { dengan } \\
\text { Ibrahim }\end{array}$ & $\begin{array}{l}\text { Ibrahim yang } \\
\text { menikah } \\
\text { dengan orang } \\
\text { lain }\end{array}$ & $\begin{array}{l}\text { Firdaus } \\
\text { sedang } \\
\text { jatuh cinta } \\
\text { dengan } \\
\text { Ibrahin }\end{array}$ & $\begin{array}{l}\text { Sebelumnya } \\
\text { firdaus } \\
\text { belum } \\
\text { pernah } \\
\text { jatuh cinta }\end{array}$ & $\begin{array}{l}\text { Ia dibawah } \\
\text { kekuasaan } \\
\text { cinta }\end{array}$ & \\
\hline 7 & $\begin{array}{l}\text { Konflik } \\
\text { Firdaus } \\
\text { dengan } \\
\text { Marzou } \\
\text { k }\end{array}$ & $\begin{array}{l}\text { Tindakan } \\
\text { Marzouk } \\
\text { yang tidak } \\
\text { disetujui oleh } \\
\text { Firdaus }\end{array}$ & $\begin{array}{l}\text { Firdaus } \\
\text { seorang } \\
\text { perempuan } \\
\text { secara fisik } \\
\text { lemah }\end{array}$ & $\begin{array}{l}\text { Banyak } \\
\text { germo } \\
\text { berebut } \\
\text { para pelacur }\end{array}$ & $\begin{array}{l}\text { Di bawah } \\
\text { kekuasaan } \\
\text { Marzouk }\end{array}$ & Hegemoni \\
\hline
\end{tabular}

3. Analisis wacana kritis berdasarkan amanat

\begin{tabular}{|l|l|l|l|l|l|l|}
\hline NO & Amanat & Tindakan & Konteks & histori & $\begin{array}{l}\text { kekuasa } \\
\text { an }\end{array}$ & Ideology \\
\hline 1 & $\begin{array}{l}\text { Untuk para } \\
\text { penguasa } \\
\text { jangn } \\
\text { berpura-pura } \\
\text { jadi orang } \\
\text { saleh padahal } \\
\text { berkelakuan } \\
\text { bejat, menipu }\end{array}$ & $\begin{array}{l}\text { Tindakan } \\
\text { para } \\
\text { penguasa } \\
\text { yang } \\
\text { sewenang- } \\
\text { wenang }\end{array}$ & $\begin{array}{l}\text { Banyaknya } \\
\text { penguasa } \\
\text { yang } \\
\text { berpura- } \\
\text { pura }\end{array}$ & $\begin{array}{l}\text { Kebiasaa } \\
\mathrm{n} \\
\text { penguasa } \\
\text { dari dulu }\end{array}$ & $\begin{array}{l}\text { Pemgua } \\
\text { sa } \\
\text { terhada } \\
\text { p } \\
\text { rakyat }\end{array}$ & Hegemoni \\
& & & & & \\
\hline
\end{tabular}




\begin{tabular}{|c|c|c|c|c|c|c|}
\hline & $\begin{array}{l}\text { rakyat, } \\
\text { memperlakuk } \\
\text { an } \\
\text { perempuan } \\
\text { dengan } \\
\text { semena-mena } \\
\text { dan memakan } \\
\text { uang rakyat. }\end{array}$ & & & & & \\
\hline 2 & $\begin{array}{l}\text { Jangan } \\
\text { mengawinkan } \\
\text { anak gadis } \\
\text { tanpa } \\
\text { bertanya atau } \\
\text { minta } \\
\text { persetujuan } \\
\text { dari yang } \\
\text { bersangkutan } \\
\text { terlebih } \\
\text { dahulu } \\
\text { karena yang } \\
\text { akan } \\
\text { merasakan } \\
\text { mereka } \\
\text { sendiri bukan } \\
\text { orang tuanya. } \\
\text { Berikan } \\
\text { kebebasan } \\
\text { terhadap } \\
\text { perempuan } \\
\text { untuk } \\
\text { memilih } \\
\text { jodohnya. }\end{array}$ & $\begin{array}{l}\text { Firdaus } \\
\text { dikawinkan } \\
\text { dengan } \\
\text { seseorang } \\
\text { tanpa } \\
\text { persetujuan } \\
\text { darinya }\end{array}$ & $\begin{array}{l}\text { Firdaus } \\
\text { hanya } \\
\text { lulusan } \\
\text { sekolah } \\
\text { menengah } \\
\text { dan sulit } \\
\text { mencari } \\
\text { pekerjaan }\end{array}$ & $\begin{array}{l}\text { Perempu } \\
\text { an harus } \\
\text { menikah }\end{array}$ & $\begin{array}{l}\text { Paman } \\
\text { Firdaus } \\
\text { berkuas } \\
\text { a atas } \\
\text { Firdaus }\end{array}$ & \\
\hline 3 & $\begin{array}{l}\text { Kehormatan } \\
\text { seseorang } \\
\text { bukan dilihat } \\
\text { dari } \\
\text { banyaknya } \\
\text { uang yang } \\
\text { dimiliki }\end{array}$ & $\begin{array}{l}\text { Pekerjaan } \\
\text { Firdaus } \\
\text { menjadi } \\
\text { seorang } \\
\text { pelacur } \\
\text { dianggap } \\
\text { tidak }\end{array}$ & $\begin{array}{l}\text { Firdaus } \\
\text { mengalami } \\
\text { ketidakadila } \\
\text { n berkali- } \\
\text { kali }\end{array}$ & $\begin{array}{l}\text { Dia } \\
\text { pernah } \\
\text { diperkos } \\
\text { a oleh } \\
\text { banyak } \\
\text { lelaki } \\
\text { dan }\end{array}$ & $\begin{array}{l}\text { Di } \\
\text { bawah } \\
\text { kekuasa } \\
\text { an laki- } \\
\text { laki }\end{array}$ & Feminisme \\
\hline
\end{tabular}




\begin{tabular}{|c|c|c|c|c|c|c|}
\hline & $\begin{array}{l}\text { tetapi dari } \\
\text { cara } \\
\text { mencarinya, } \\
\text { seperti } \\
\text { firdaus yang } \\
\text { banyak uang } \\
\text { tetapi dengan } \\
\text { cara } \\
\text { melacurkan } \\
\text { diri tetap saja } \\
\text { ia tidak } \\
\text { menjadi } \\
\text { terhormat } \\
\text { walaupun } \\
\text { banyak uang. }\end{array}$ & terhormat & & $\begin{array}{l}\text { tuntutan } \\
\text { ekonomi }\end{array}$ & & \\
\hline 4 & $\begin{array}{l}\text { Perlakukan } \\
\text { secara baik } \\
\text { dan adil } \\
\text { seluruh } \\
\text { karyawan } \\
\text { jangan } \\
\text { sombong } \\
\text { dengan } \\
\text { jabatan }\end{array}$ & $\begin{array}{l}\text { Banyak } \\
\text { karyawan } \\
\text { yang } \\
\text { diperlakukan } \\
\text { tidak adil }\end{array}$ & $\begin{array}{l}\text { Setiap } \\
\text { orang ingin } \\
\text { sesuatu } \\
\text { yang lebih } \\
\text { termasuk } \\
\text { para } \\
\text { pimpinan }\end{array}$ & $\begin{array}{l}\text { Atasan } \\
\text { punya } \\
\text { kekusaan }\end{array}$ & $\begin{array}{l}\text { Berkua } \\
\text { sa atas } \\
\text { karyaw } \\
\text { annya }\end{array}$ & Hegemoni \\
\hline 5 & $\begin{array}{l}\text { Jangan } \\
\text { memperlakua } \\
\text { kn } \\
\text { perempuan } \\
\text { dengan } \\
\text { semena-mena } \\
\text {, hormatilah } \\
\text { kaum } \\
\text { perempuan, } \\
\text { jangan } \\
\text { menjadikann } \\
\text { ya budak } \\
\text { dalam rumah } \\
\text { tangga }\end{array}$ & $\begin{array}{l}\text { Banyak } \\
\text { perempuan } \\
\text { yang } \\
\text { mendapatkan } \\
\text { ketidakadilan } \\
\text { di } \\
\text { rumahtangga } \\
\text { maupun } \\
\text { tempat kerja }\end{array}$ & $\begin{array}{l}\text { Perempuan } \\
\text { dianggap } \\
\text { aum lemah }\end{array}$ & $\begin{array}{l}\text { Laki-laki } \\
\text { selalu } \\
\text { jadi } \\
\text { penguasa }\end{array}$ & $\begin{array}{l}\text { Karena } \\
\text { laki- } \\
\text { laki } \\
\text { berkuas } \\
\text { a maka } \\
\text { ini } \\
\text { bentuk } \\
\text { protesn } \\
\text { ya }\end{array}$ & Feminisme \\
\hline
\end{tabular}




\section{DAFTAR PUSTAKA}

Darma, Yoce Aliah.(2009). Analisis Wacana Kritis. Bandung: Yrama Widya.

Djajasudarma, T.fatimah.(2012). Wacana \&Pragmatik. Bandung: Refika Aditama.

Eriyanto.(2005).Analisis Wacana.Yogyakarta: LKiS.

Mulyana.(2005). Kajian Wacana. Yogyakarta: Tiara Wacana.

Nurgiyantoro, Burhan.(2009). Teori Pengkajian Fiksi. Yogyakarta: Gadjah Mada University Press.

Saadawi, Naawal.(2006). Perempuan Di Titik Nol. Jakarta; Yayasan Obor Indonesia

Sugiyono. (2012). Metode Penelitian Kuantitatif, Kualitatif dan R\&D. Bandung: Alfabeta.

Syamsudin.(1992). Studi Wacana. Bandung: Mimbar Pendidikan Bahasa dan Seni FPBS IKIP Bandung.

Tarigan. Pengajaran wacana. Bandung: Offset Angkasa 